\title{
Biodiversity in vegetable crops, a heritage to save: the case of Puglia region
}

\author{
Antonio Elia, ${ }^{1}$ Pietro Santamaria ${ }^{2}$ \\ ${ }^{1}$ Department of the Science of Agriculture, Food and Environment (SAFE), University of Foggia; \\ ${ }^{2}$ Department of Agricultural and Environmental Science, University of Bari Aldo Moro, Italy
}

\begin{abstract}
The biodiversity in vegetable crops is composed by the genetic diversity, as species diversity (interspecific diversity) and as diversity of genes within a species (intraspecific diversity) referring to the vegetable grown varieties, and by the diversity of agro-ecosystems (agrobiodiversity). Intraspecific diversity is very ample in vegetable crops and is not reflected, at least not to the same extent, in other groups of crops. The labour operated by farmers over centuries of selection has led to the creation of a plurality of local varieties, following domestication of cultivated forms, and wide agro-biodiversity, a precious heritage both from a genetic and a cultural-historical point of view. The Italian National Statistical Institute (ISTAT) takes into account in its annual survey about forty vegetable crops. Intraspecific diversity in vegetables can also be analyzed by examining the information contained in the common catalogue of varieties of vegetable species. The 27 EU Countries as a whole had entered 19,576 varieties of vegetables in the common catalogue as of August 2011. The Netherlands, which represents $8 \%$ of total vegetable production in the $\mathrm{EU}$, has registered 7826 varieties. Italy and Spain, which predominate in Europe for the production of vegetables, have registered only $8 \%$ (1513) and 9\% (1672) of the total varieties, respectively. As a whole $54 \%$ of the European varieties entered in the catalogue are hybrids. Puglia, which contributes with about $22 \%$ to the Italian vegetable growing area, is
\end{abstract}

Correspondence: Antonio Elia, Department of the Science of Agriculture, Food and Environment (SAFE), University of Foggia, via Napoli 25, 71100 Foggia, Italy. E-mail: a.elia@unifg.it

Key words: agro-biodiversity, local vegetable varieties, edible wild species, genetic erosion, Agri-food Traditional Products, Rural Development Program of Puglia; seed companies.

Conference presentation: SIA Congress, Bari 2012.

Acknowledgments: this study has been supported by Puglia Region within the Puglia, Rural Development Program 2007-13.

Received for publication: 13 November 2012.

Revision received: 23 January 2013.

Accepted for publication: 26 January 2013.

(C) Copyright A. Elia and P. Santamaria, 2013

Licensee PAGEPress, Italy

Italian Journal of Agronomy 2013; 8:e4

doi:10.4081/ija.2013.e4

This article is distributed under the terms of the Creative Commons Attribution Noncommercial License (by-nc 3.0) which permits any noncommercial use, distribution, and reproduction in any medium, provided the original author(s) and source are credited. among the leading regions for the productions of broccoli raab, celery, parsley, processing tomato, artichoke, endive and escarole, cabbage, fennel, lettuce, cucumber, cauliflower and broccoli, early potato, and asparagus (all with more than $20 \%$ of the national area). The region is particularly rich in local vegetable varieties, obtained by farmers themselves after repeated simple selection procedures generation after generation. The local varieties for which there is a strong link with the Puglia traditions and which are described in this review are: carota $d i$ Polignano (Polignano carrot) and carota di sant'Ippazio (Saint Ippazio carrot) (Apiaceae), cipolla di Acquaviva delle Fonti (Acquaviva delle Fonti onion) and cipolla bianca di Margherita (Margherita white onion) (Liliaceae), cima di rapa (broccoli raab) (Brassicaceae), unripe melon - carosello, barattiere, meloncella, etc. (Cucurbitaceae), catalogna chicory - cicoria di Molfetta e cicoria di Galatina (Molfetta's chicory and Galatina's chicory) (Asteraceae).

\section{Biodiversity and agro-biodiversity}

The term biodiversity, a neologism coined by the entomologist Edward 0. Wilson in 1986, is intended here as the entire variability or varieties of living-forms (Wilson, 1992). Agro-biodiversity is a part of biodiversity and represents the diversity of cultivated agricultural systems (agro-ecosystems) in relation to: i) genes and combinations of genes within each species; ii) species; iii) combinations of biotic and abiotic elements that define the various agro-ecosystems.

Biodiversity and agro-biodiversity are new concepts which are not immediately understood by the general public. In fact, from a survey of the Attitudes of Europeans towards the issue of biodiversity (Eurobarometer, 2010) the majority of European citizens admit that they do not feel adequately informed on biodiversity. Only $38 \%$ of Europeans know the meaning of the term biodiversity, while $28 \%$ stated that they had already heard this word but do not know what it means. The majority of European citizens believe that the loss of biodiversity is a serious threat, even if they think this loss will not affect their life directly; only $17 \%$ of the interviewers admit to already feeling this as a direct problem. To the question on which are the most serious threats to biodiversity, $27 \%$ of interviewers indicate pollution, while $26 \%$ of them refer to disasters caused by humans. European citizens explain their inertia toward this problem with the fact that they are poorly informed on actions to be taken.

Biodiversity of crops is characterized by a number of historical genetic bottlenecks imposed on crop plants during domestication and through modern plant breeding (Tanksley and McCouch, 1997), i.e. critical moments diminishing this diversity. The first was the result of domestication of crops in which only a subset of the diversity of the wild species remained after repeated selection for desired traits: humans focused attention only on certain species that were considered the most interesting for their food supply and within these species exerted a selective pressure toward specific phenotypes, thus 
causing a reduction in the number of species used in their needs and a reduction in allelic diversity of the same. This was followed by a dispersal phase which arose when only a subset of the crop was exported to another region, in which diversity was further reduced through adaptive selection to the new conditions (Zeder et al., 2006). This last case led, for example, to the famine in Ireland caused by potato blight exerting its disastrous effect as result of the narrow genetic base of the cultivated potato in comparison with those in the Andes areas of origin. The last biodiversity narrowing phase is the result of modern scientific plant breeding that replaced genetically diverse landraces with uniform varieties, mainly $F_{1}$ hybrids in vegetables (Dias, 2011). In addition to natural selection, the work of farmers has had an important role in the process of creating agro-biodiversity. Operating generation after generation by repeated simple selection procedures, they have recognized and retained in cultivation new variants deemed of a certain utility, causing a net increase in diversity (van de Wouw et al., 2010), so that domestication can be considered the base of agricultural diversity (Frankel et al., 1995).

\section{Agro-biodiversity characteristics in vegetable crops}

Agro-biodiversity in vegetable crops is composed by the genetic diversity, as species diversity (interspecific diversity) and as diversity of genes within a species (intraspecific diversity) referring to the vegetable grown varieties, and by the diversity of agro-ecosystems. Species richness is also linked to the use, also in the same species, of different parts of the plant. All organ structures of the plant, often metamorphosed, are used as vegetables (Table 1).

There are many ways of classification used with vegetables crops, which refer for example to: the part of the plant used (Table 1), destination use, adaptability to the climatic conditions, resistance to abiotic stresses, nutritional composition, harvesting time period, aptitude to post-harvest storage, etc. Even this is an expression of biodiversity.

Intraspecific diversity is very ample in vegetable crops and is not reflected, at least not to the same extent, in other groups of crops. The labour operated by farmers over centuries of selection has led to the creation of a plurality of local varieties, following domestication of cultivated forms, and wide agro-biodiversity, a precious heritage both from a genetic and a cultural-historical point of view. In the case of vegetable crops agro-biodiversity has assumed very articulated connotations [A local variety (also called: landrace, farmer's variety, folk variety) is a population of a seed- or vegetative-propagated crop characterized by greater or lesser genetic variation, which is however well identifiable and which usually has a local name. It has not been subjected to an organized program of genetic improvement, and is also characterized by a specific adaptation to the environmental and the cultivation conditions of the particular area where it has been selected (Zeven, 1998). It is closely associated with the traditions, the knowledge, the habits, the dialects and the occurrences of the human population that have developed it and/or continue its cultivation (Bianchi et al., 2012)].

Today this biodiversity meets and stimulates the various requirements of the market (in terms of new types of product, quality standard, and rediscovery of traditions), of the production sector (in terms of plants more adaptable to climate change, new cultivation methods and cultivation environments or biotic stresses) as well as the needs of the processing industry and of modern distribution (La Malfa and Bianco, 2006). At the same time, this generates the rapid obsolescence of cultivars and the fast turnover of available cultivar assets, especially in terms of F1 hybrid availability.

\section{Consistency of the vegetable crop production}

The Italian National Statistical Institute (ISTAT) takes into account in its annual survey about forty vegetable crops, including 38 species for

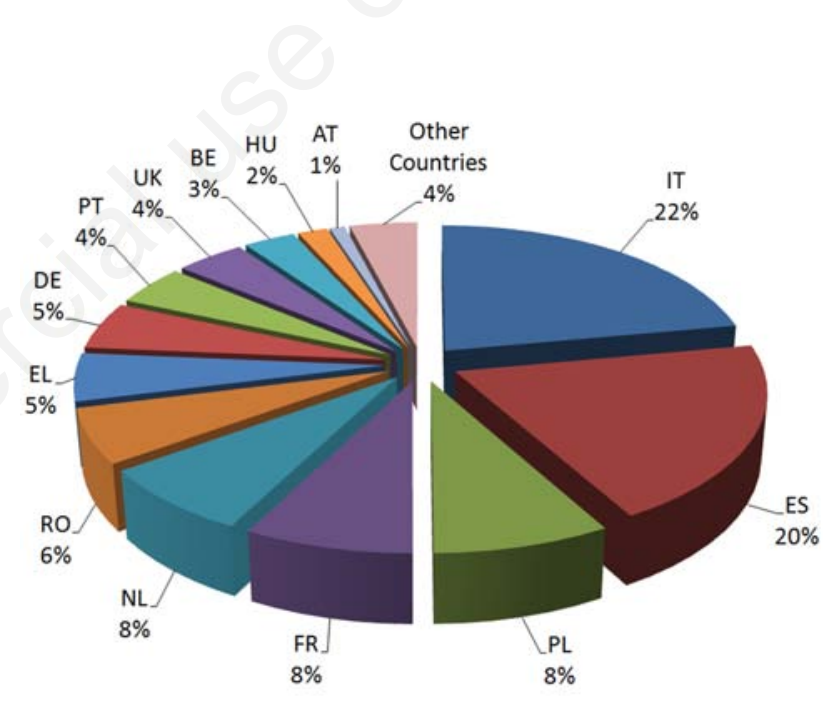

Figure 1. Vegetable production in Europe. AT, Austria; BE, Belgium; DE, Germany; EL, Greece; ES, Spain; FR, France; HU, Hungary; IT, Italy; NL, Netherlands; PL, Poland; PT, Portugal; RO, Romania; UK, United Kingdom. (Source: FAOSTAT, 2012. Available from: http://faostat.fao.org/default.aspx).

Table 1. Main examples of the various plant organs used as edible part in vegetable species.

\begin{tabular}{ll} 
Plant part & \\
Bulb & Garlic, lampascione, onion, shallot \\
Root & Beet, carrot, radish (enlarged hypocotyl), celeriac \\
\hline Tuber & Sweet potato, potato \\
Stem & Asparagus, kohlrabi (enlarged epicotyl), chicory \\
\hline Infiorescence & Artichoke, cauliflower, broccoli, broccoli raab \\
Flower & Caper, zucchini/courgette flower (male), saffron \\
\hline Fresh seeds & Bean, fava bean, pea \\
Leaves & Basil, Swiss chard, Brussels sprouts, cabbage, Chinese cabbage, savoy cabbage, fennel, endive, lettuce, parsley, radicchio chicory, escarole, celery \\
\hline Fruit & Cucumber, watermelon, peas, sweet corn, melon, pepper, tomato, mange tout, pumpkin, zucchini/courgette \\
False fruit & Strawberry
\end{tabular}


which the register of Italian varieties was started and made mandatory in 1976 (Benedetti, 1973). These species, of course, are also included in the group of 46 species listed in the latest edition of the common catalogue of varieties of vegetable species published in 2011 (EU-27 Countries). La Malfa and Bianco (2006) expanded the horizon and estimate that the vegetables cultivated at an European level could exceed 200 crops (Table 2). In fact, they considered: i) the approximately 180 crops included in the Trattato di Orticoltura (Viani, 1929) published in Catania; ii) the 90 common species and the 100 minor species examined by Vilrnorin Andrieux, one of the greatest connoisseurs of French horticulture, in his book Les plantes potageres, 1904 edition. A greater number of vegetable crops are cultivated worldwide: 382 according to Rubatzkj and Yamaguchi (1997) and 392 according to Kays and Dias $(1995,1996)$, representing in this case 70 families and 225 genera. The list can be considerably extended if non-cultivated species, lower organisms (e.g. fungi), most trees and woody shrubs, and plants grown in or gathered from salt water, are included. The Chinese have lists of about 600 species that cover a high share of biodiversity used around the world for the production of vegetables or similar products (La Malfa, 1997; Lee, 1992; Lin Chao, 1989) (Table 2).

\section{European and Italian framework of registered vegetable varieties}

Italy is the leading country in Europe for the production of vegetables, representing $22 \%$ of the total production (14.2 million tons) (Figure 1). It is followed by Spain (12.7 million tons), Poland (5.2), France (4.9) and The Netherlands (4.8). Two thirds of the Italian vegetable cultivation (328,933 ha) is concentrated in the Southern part of the Country with a production of 7.8 million tons out of a total of 14.2 on national basis (FAOSTAT, 2012). Intraspecific diversity in vegetables can also be analyzed by examining the information contained in the common catalogue of varieties of vegetable species, now in its thirtieth edition, which reflects the situation in August 2011. Obviously, only varieties which are distinct, stable and sufficiently uniform and, in the case of agricultural species, with an appropriate value for cultivation or use (the so-called bred varieties [i.e., a variety which derives from a specific genetic improvement program conducted by plant breeders. Homogeneous populations, often consisting of a single genotype (pure lines, simple hybrids, clones) (Bianchi et al., 2012)], can be entered in the official catalogue by member States.

The 27 EU Countries as a whole had entered 19,576 varieties of vegetables in the common catalogue as of August 2011 (European Commission, 2011). The Netherlands, which represents $8 \%$ of total vegetable production in the EU (Figure 1), has registered 7826 varieties (Figure $2 ; 40 \%$ of the total). Italy and Spain (Figure 2), which predominate in Europe for the

Table 2. Crops, spontaneous species and cultivars reported in documents and in bibliographic references (revised from: La Malfa and Bianco, 2006).

\begin{tabular}{lc} 
Source & Number \\
Viani, 1929 & 180 \\
Lin Chao, 1989 & 573 \\
\hline Bianco, 1990a; 1990b & $144-275^{\circ}$ \\
Branca, 1991 & $410^{\circ}$ \\
\hline Bianco, 1992 & 174 \\
Leonardi, 1993 & 1482 \\
\hline Rubatzky and Yamaguchi, 1997 & 382 \\
Kays and Dias, 1995, 1996 & 392 \\
\hline Bianco et al., 2001 & $690^{\circ}$ \\
Bianco and Machackova, 2002 & 808 \\
\hline Italian catalogue vegetable varieties & $(38)-1513^{\sharp \S}$ \\
European catalogue vegetable varieties - EU 27 countries & $(46)-19,576^{\sharp}$ \\
\hline
\end{tabular}

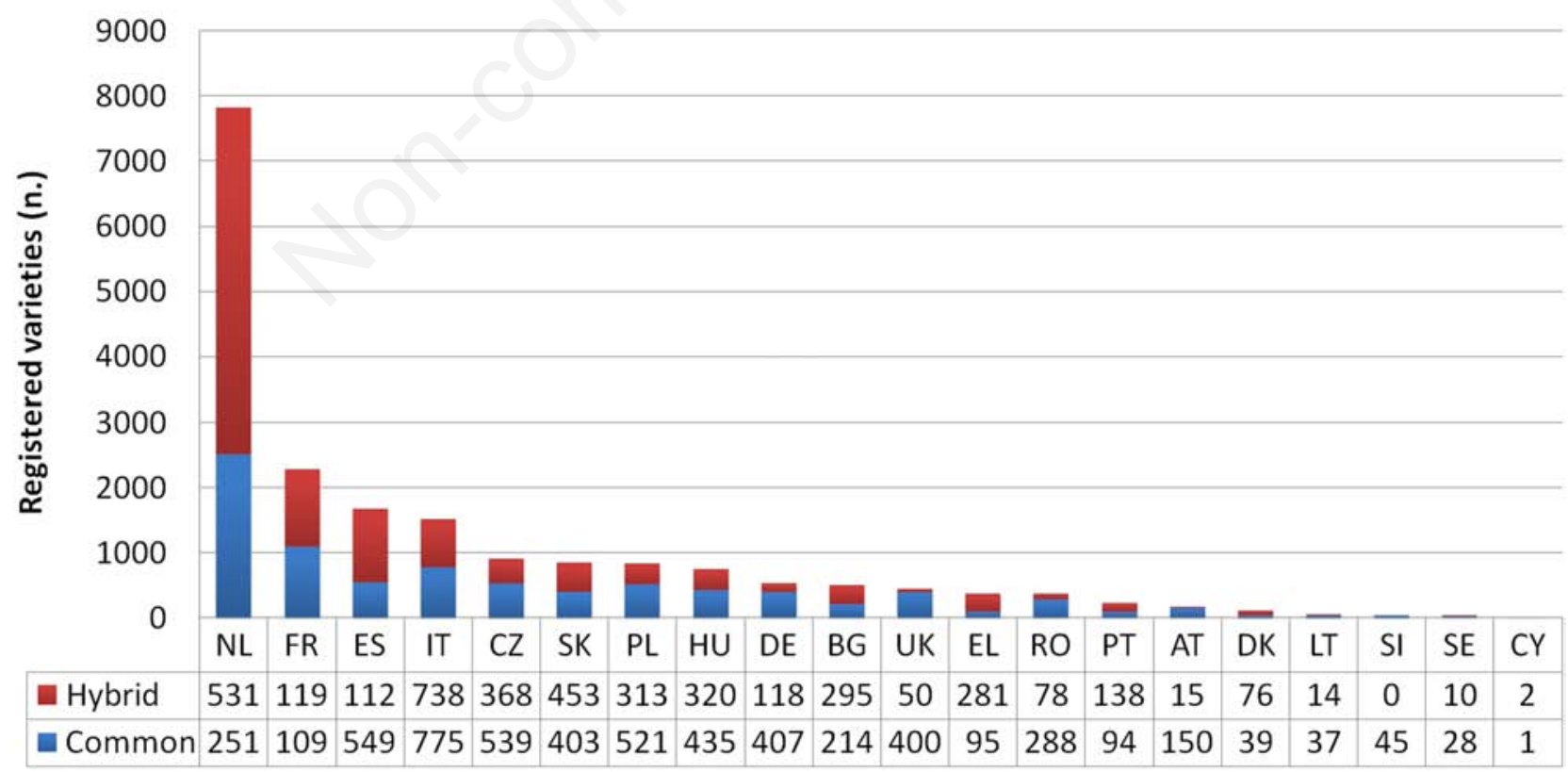

Figure 2. Number of total, hybrid and common varieties registered in the European vegetable catalogue by the EU-27 countries (our elaboration). AT, Austria; BE, Belgium; BG, Bulgaria; CY, Cyprus; CZ, Czech Republic; DE, Germany; EL, Greece; ES, Spain; FR, France; HU, Hungary; IT, Italy; LT, Lithuania; NL, Netherlands; PL, Poland; PT, Portugal; RO, Romania; SE, Sweden; SI, Slovenia; SK, Slovakia; UK, United Kingdom. 
production of vegetables (Figure 1), have registered only 8\% (1513 in number) and 9\% (1672 in number) of the total varieties, respectively.

The European situation shows that in The Netherlands the commercial vegetable breeding sector is more based on large and well organized seed companies with good scientific manpower and well equipped research facilities and is able to produce a continuous flow of innovative new varieties for a number of vegetables. Seven Dutch seed companies alone possess approximately 5100 varieties (Table 3 ), more than a quarter of the total registered varieties in Europe. In the other Countries, breeding is more based on traditional procedures where breeders, on the basis of considerable knowledge and experience about traits of the reproductive material, have made crosses and selected the most suitable plants. As a whole $54 \%$ of the European varieties entered in the catalogue are hybrids. In particular, as shown in Figure 2, The Netherlands has 5313 hybrids (68\%), France 1191 (52\%), Spain 1672 (67\%), and Italy 738 (49\%). In the other EU Countries with less than 1000 varieties each, the incidence of hybrids ranges from the high values observed in Greece (75\%), Denmark (66\%), Portugal (59\%) and Bulgaria (58\%), to the low values observed in Germany (22\%), Romania (21\%), the United Kingdom (11\%), Austria (9\%) and Slovenia (0\%). On average the incidence of hybrids in these countries is $41 \%$ (Figure 2). It is however clear that there is a high articulation both at the level of botanical varieties and especially of cultivars; the number continues to increase (the first publication of the catalogue dates back to 29 June 1972), especially for hybrid varieties, as shown in Figure 3 for Italy. From Table 3 the high specialization of the Dutch seed industry is evident, as is the gap compared with the other European nations. The Dutch seed industry is strongly focused in supporting modern horticulture and is aimed at trying to continuously increase the panorama of varieties, with hybrids that are competitive, innovative in terms of resistance against pests and diseases, have increased yield, quality improvement (such as shelf-life, taste), and increased production efficiency. However, the small scale seed companies that operate mainly

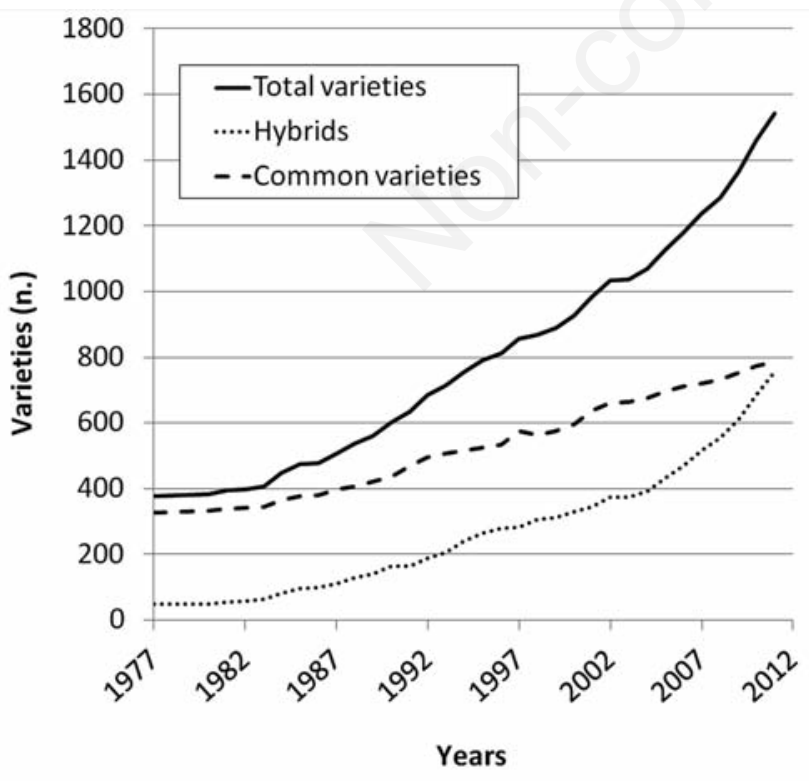

Figure 3. Number of varieties (common and hybrid) registered in the European and National Catalogues of Italian vegetables varieties from 1977 to 2011 (our elaboration of data from SIAN, 2012).

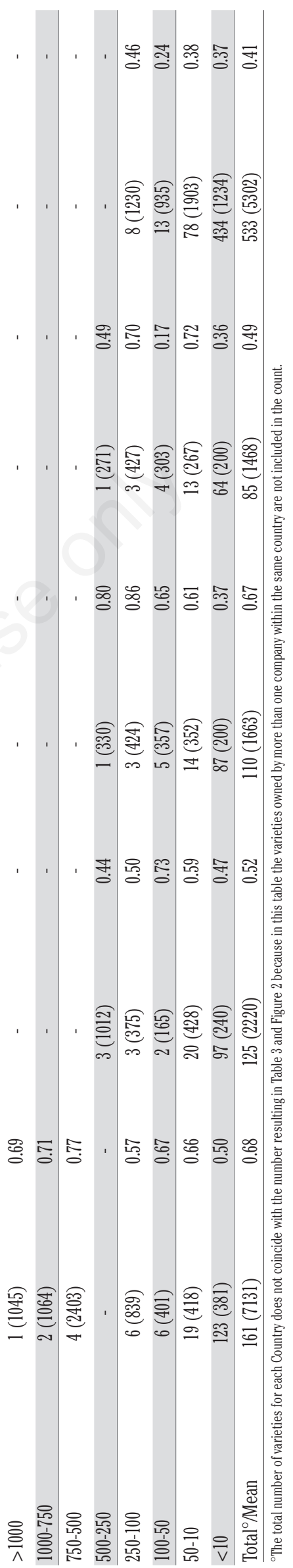


Table 4. Number of varieties registered for single species and typology in the common catalogue of vegetable variety for the top ten countries in the number of entries (13 ${ }^{\text {th }}$ edition) (our elaboration of data from: European Commission, 2011).

\begin{tabular}{|c|c|c|c|c|c|c|c|c|c|c|c|c|}
\hline \multirow[t]{2}{*}{ Species/common name of different types } & \multicolumn{12}{|c|}{ Country } \\
\hline & NL & FR & ES & IT & CZ & SK & PL & $\mathrm{HU}$ & $\mathrm{DE}$ & BG & Other & Total \\
\hline Lycopersicon esculentum Mill. - Tomato & 1353 & 311 & 387 & 461 & 75 & 97 & 96 & 67 & 36 & 145 & 359 & 3494 \\
\hline Brassica oleracea $\mathrm{L}$. & 1040 & 232 & 62 & 67 & 138 & 152 & 48 & 48 & 79 & 53 & 233 & 2317 \\
\hline Curly kale & 16 & 1 & 2 & 0 & 7 & 1 & 0 & 0 & 3 & 0 & 4 & 39 \\
\hline Cauliflower & 333 & 139 & 18 & 25 & 22 & 28 & 6 & 8 & 3 & 13 & 79 & 731 \\
\hline Sprouting broccoli/Calabrese & 86 & 17 & 9 & 16 & 9 & 8 & 5 & 5 & 4 & 6 & 11 & 187 \\
\hline Brussels sprouts & 78 & 3 & 3 & 1 & 2 & 1 & 0 & 0 & 3 & 1 & 12 & 107 \\
\hline Savoy cabbage & 98 & 18 & 6 & 14 & 10 & 23 & 2 & 5 & 7 & 0 & 10 & 218 \\
\hline White cabbage & 325 & 43 & 16 & 9 & 57 & 62 & 28 & 23 & 27 & 27 & 106 & 774 \\
\hline Red cabbage & 60 & 10 & 6 & 1 & 13 & 9 & 3 & 1 & 11 & 4 & 4 & 127 \\
\hline Kohlrabi & 44 & 1 & 2 & 1 & 18 & 20 & 4 & 6 & 21 & 2 & 7 & 134 \\
\hline Lactuca sativa L. - Lettuce & 926 & 358 & 110 & 114 & 89 & 38 & 55 & 21 & 38 & 28 & 82 & 2045 \\
\hline Capsicum annuum L. - Chili, Pepper & 729 & 116 & 286 & 132 & 163 & 150 & 52 & 217 & 16 & 49 & 155 & 2128 \\
\hline Cucumis sativus L. & 585 & 48 & 104 & 23 & 87 & 75 & 119 & 40 & 37 & 60 & 118 & 1357 \\
\hline Cucumber & 442 & 42 & 100 & 19 & 38 & 40 & 47 & 21 & 23 & 35 & 89 & 928 \\
\hline Gherkin & 143 & 6 & 4 & 4 & 49 & 35 & 72 & 19 & 14 & 25 & 29 & 429 \\
\hline Phaseolus vulgaris L. & 484 & 184 & 105 & 116 & 25 & 37 & 75 & 52 & 54 & 31 & 106 & 1380 \\
\hline Dwarf French bean & 404 & 162 & 60 & 73 & 14 & 29 & 72 & 45 & 39 & 26 & 60 & 1059 \\
\hline Climbing French bean & 80 & 22 & 45 & 43 & 11 & 8 & 3 & 7 & 15 & 5 & 46 & 321 \\
\hline Allium cepa L. - & 473 & 65 & 84 & 75 & 49 & 49 & 72 & 37 & 12 & 14 & 93 & 1110 \\
\hline Aggregatum group - Shallot & 29 & 14 & 0 & 0 & 0 & 0 & 1 & 1 & 0 & 0 & 3 & 50 \\
\hline Cepa group - Onion, Echalion & 444 & 51 & 84 & 75 & 49 & 49 & 71 & 36 & 12 & 14 & 90 & 1060 \\
\hline Cucumis melo L. - Melon & 256 & 271 & 171 & 55 & 0 & 16 & 8 & 16 & 0 & 20 & 77 & 947 \\
\hline Daucus carota L. - Carrot & 251 & 62 & 11 & 12 & 61 & 51 & 60 & 13 & 26 & 10 & 48 & 669 \\
\hline Carrot & 251 & 60 & 11 & 12 & 58 & 51 & 58 & 13 & 25 & 10 & 48 & 659 \\
\hline Fodder carrot & 0 & 2 & 0 & 0 & 3 & 0 & 2 & 0 & 1 & 0 & 0 & 10 \\
\hline Spinacia oleracea L. - Spinach & 221 & 14 & 8 & 12 & 5 & 4 & 5 & 3 & 6 & 3 & 39 & 345 \\
\hline Pisum sativum L. (Partim) - Pea & 204 & 91 & 19 & 40 & 22 & 38 & 31 & 72 & 74 & 23 & 133 & 837 \\
\hline Wrinkled pea & 155 & 45 & 12 & 25 & 21 & 38 & 25 & 67 & 63 & 22 & 119 & 635 \\
\hline Round pea & 17 & 40 & 3 & 13 & 0 & 0 & 1 & 5 & 6 & 1 & 7 & 130 \\
\hline Sugar pea & 32 & 6 & 4 & 2 & 1 & 0 & 5 & 0 & 5 & 0 & 7 & 72 \\
\hline Citrullus lanatus (Thunb.) Matsum. et Nakai - Watermelon & 163 & 22 & 89 & 52 & 0 & 26 & 4 & 18 & 1 & 17 & 62 & 467 \\
\hline Cucurbita pepo L. - Marrow or courgette & 155 & 93 & 58 & 86 & 17 & 7 & 21 & 14 & 4 & 13 & 78 & 598 \\
\hline Raphanus sativus L. & 124 & 48 & 12 & 20 & 51 & 21 & 52 & 5 & 43 & 6 & 37 & 471 \\
\hline Radish & 105 & 41 & 10 & 18 & 42 & 18 & 49 & 4 & 28 & 3 & 27 & 389 \\
\hline Black radish & 19 & 7 & 2 & 2 & 9 & 3 & 3 & 1 & 15 & 3 & 10 & 82 \\
\hline Cichorium endivia L. - Endive & 112 & 60 & 10 & 36 & - & - & - & - & 3 & - & 4 & 277 \\
\hline Curled-leaved endive & 56 & 34 & 8 & 16 & - & - & - & - & 1 & - & 3 & 147 \\
\hline Plain-leaved endive & 56 & 26 & 2 & 20 & - & - & - & - & 2 & - & 1 & 130 \\
\hline Allium porrum L. - Leek & 109 & 26 & 8 & 5 & 14 & 9 & 13 & 1 & 7 & 4 & 22 & 250 \\
\hline Solanum melongena L. - Aubergine/Egg Plant & 100 & 34 & 36 & 42 & - & 6 & 3 & 4 & 2 & 11 & 34 & 290 \\
\hline Apium graveolens L. & 67 & 6 & 9 & 10 & 12 & 8 & 7 & 6 & 8 & - & 19 & 182 \\
\hline Celery & 46 & 6 & 9 & 8 & 4 & 1 & 2 & 1 & - & - & 13 & 116 \\
\hline Celeriac & 21 & - & - & 1 & 8 & 7 & 5 & 5 & 8 & - & 6 & 65 \\
\hline Brassica rapa $\mathrm{L}$. & 83 & 23 & 17 & 8 & 25 & 1 & 6 & 4 & 8 & 2 & 40 & 281 \\
\hline Chinese cabbage & 52 & 2 & 5 & - & 24 & 1 & 5 & 3 & 2 & 2 & 3 & 107 \\
\hline Turnip & 31 & 21 & 12 & 8 & 1 & - & 1 & 1 & 6 & - & 37 & 174 \\
\hline Cichorium intybus L. & 61 & 55 & - & 50 & 7 & - & 2 & 2 & - & - & 13 & 236 \\
\hline Witloof chicory & 16 & 35 & - & 1 & 1 & - & - & 2 & - & - & 1 & 59 \\
\hline Large-leaved chicory/Italian chicory & 33 & 5 & - & 49 & 4 & - & - & - & - & - & 3 & 135 \\
\hline Industrial chicory & 12 & 15 & - & - & 2 & - & 2 & - & - & - & 9 & 42 \\
\hline Beta vulgaris $\mathrm{L}$. & 51 & 16 & 12 & 18 & 12 & 5 & 24 & 4 & 8 & 1 & 40 & 230 \\
\hline Beetroot, including Cheltenham beet & 43 & 11 & 3 & 3 & 12 & 5 & 24 & 4 & 5 & 1 & 34 & 164 \\
\hline Spinach beet or Swiss chard & 8 & 5 & 9 & 15 & - & - & - & - & 3 & - & 6 & 66 \\
\hline Phaseolus Coccineus L. - Runner bean & 46 & 1 & - & 2 & 1 & 2 & 7 & 1 & 1 & 4 & 21 & 104 \\
\hline
\end{tabular}


Table 4. Continued from the previous page.

\begin{tabular}{|c|c|c|c|c|c|c|c|c|c|c|c|c|}
\hline \multirow[t]{2}{*}{ Species/common name of different types } & \multicolumn{12}{|c|}{ Country } \\
\hline & NL & FR & ES & IT & CZ & SK & PL & HU & DE & BG & Other & Total \\
\hline Zea mays L. & 35 & 23 & 2 & 1 & 5 & 41 & 15 & 90 & 2 & 8 & 13 & 259 \\
\hline Sweet corn & 35 & 19 & 2 & 1 & 5 & 33 & 12 & 68 & 2 & 5 & 13 & 217 \\
\hline Popcorn & - & 4 & - & - & - & 8 & 3 & 22 & - & 3 & - & 42 \\
\hline Foeniculum vulgare Mill. - Fennel & 27 & 16 & 1 & 25 & 1 & - & - & 3 & 1 & - & - & 81 \\
\hline Cucurbita maxima Duchesne - Gourd & 26 & 4 & 4 & 4 & 2 & 2 & 7 & 3 & 2 & - & 10 & 72 \\
\hline Vicia faba L. - Broad bean & 24 & 3 & 21 & 16 & 2 & 4 & 16 & 2 & 2 & 1 & 21 & 132 \\
\hline Allium fistulosum L. - Japanese bunching onion/Welsh onion & 20 & 2 & 1 & - & 2 & 3 & 3 & - & 4 & 2 & 2 & 39 \\
\hline Cynara cardunculus L. - & 9 & 14 & 14 & 11 & - & - & - & - & 1 & - & - & 58 \\
\hline Globe artichoke & 8 & 10 & 11 & 6 & - & - & - & - & - & - & - & 37 \\
\hline Cardoon & 1 & 4 & 3 & 5 & - & - & - & - & 1 & - & - & 21 \\
\hline Valerianella locusta (L.) Laterr. - Corn salad/Lamb’s lettuce & 20 & 19 & - & 1 & - & - & - & - & 12 & - & 2 & 59 \\
\hline Allium schoenoprasum L. - Chives & 17 & 1 & - & - & 4 & - & 3 & - & 6 & - & 2 & 33 \\
\hline Petroselinum crispum (Mill.) Nyman ex A. W. Hill - Parsley & 15 & 5 & 3 & 4 & 16 & 10 & 20 & 7 & 13 & 1 & 16 & 135 \\
\hline Rheum rhabarbarum L. - Rhubarb & 16 & - & - & - & - & - & 1 & - & - & - & 1 & 19 \\
\hline Asparagus officinalis L. - Asparagus & 13 & 22 & 10 & 8 & - & - & 2 & 1 & 16 & - & - & 84 \\
\hline Scorzonera hispanica L. - Scorzonera/Black salsify & 5 & - & - & - & 1 & - & - & - & 1 & - & 2 & 12 \\
\hline Allium sativum L. - Garlic & 3 & 35 & 18 & 7 & 20 & 5 & 7 & 4 & 1 & 1 & 11 & 120 \\
\hline Anthriscus cerefolium (L.) Hoffm. - Chervil & 3 & 1 & - & - & - & - & - & - & 1 & - & - & 7 \\
\hline Total & 7826 & 2281 & 1672 & 1513 & 906 & 857 & 834 & 755 & 525 & 507 & 1893 & 21,125 \\
\hline
\end{tabular}

BG, Bulgaria; CZ, Czech Republic; DE, Germany; ES, Spain; FR, France, HU, Hungary; IT, Italy; NL, Netherlands; PL, Poland; SK, Slovakia.

through open-pollinated varieties are those that retain the local varieties germplasm and therefore play a more important role in terms of maintenance and preservation of biodiversity in the vegetable crop sector. The most represented species (with more than 50 cultivars) are shown in descending order in Table 4. The Netherlands has the highest number of registered varieties for 17 different types of vegetables; France for melon, asparagus, witloof chicory, industrial chicory and garlic; Italy for cardoon, large-leaved chicory and spinach beet; Poland for parsley; Spain, for artichoke; Hungary for sweet corn (Table 4).

The most represented species for Italy are: tomato (461 registered varieties; 368 of which are hybrids), pepper (132; 92 of which are hybrids), bean (116), lettuce (114), zucchini/courgette (86; 66 of which are hybrids), onion (75; 14 of which are hybrids), cauliflower and cabbage ( $67 ; 22$ of which are hybrids), melon ( $55 ; 48$ of which are hybrids), watermelon ( $52 ; 47$ of which are hybrids).

To the above 1513 Italian varieties, must be added 57 potato cultivars (46 recorded after 2000 and the three older ones in 1987), which are included in the catalogue of varieties of agricultural plant species.

For the Italian cultivation of potato it must be pointed out that there is: i) a strong dependence from abroad for the supply of the tuberseeds; ii) a considerable presence in agri-food tradition in the country; iii) a contraction of $65 \%$ of the cultivated area from 1982 to 2010 (ISTAT, 2012); iv) the delay in the work of genetic improvement. In the common catalogue of varieties of vegetable species, there are only two seed company in the Puglia region responsible for the conservation of 24 cultivars, including mainly Asteraceae, Brassicaceae and Liliaceae.

\section{Genetic erosion in Italy}

In Italy the vegetable crop growing area is mainly concentrated in territories with milder temperatures and with greater availability of
Table 5. Genetic erosion estimated as number of landraces lost per year in various crops resulting from collecting campaigns in 1950 and in 1983/86 in Southern Italy (modified from Hammer and Laghetti, 2005).

\begin{tabular}{|c|c|c|c|c|}
\hline Crop & $\begin{array}{r}\text { Ye } \\
1950 \text { (no.) }\end{array}$ & $\begin{array}{l}\text { ars } \\
\text { 1983/86 (no.) }\end{array}$ & $\begin{array}{l}\text { Var. } \\
(\%)\end{array}$ & $\begin{array}{l}\text { Genetic erosion } \\
\text { (no./year) }\end{array}$ \\
\hline Cereals & 31 & 9 & -71.0 & 3.60 \\
\hline Vegetables & 38 & 7 & -81.6 & 4.95 \\
\hline Pulses & 29 & 11 & -62.1 & 2.80 \\
\hline Other crops & 5 & 1 & -80.0 & 4.70 \\
\hline Total & 103 & 28 & -72.8 & 3.79 \\
\hline
\end{tabular}

Var, variation.

water for irrigation. There has been a severe decline in the vegetable variety genetic base, as evidenced by the significant reduction in the number and range of vegetable varieties grown, especially in the last 50 years. During this period vegetable genetic biodiversity has been eroded all over the world and vegetable genetic resources are disappearing on a global scale at an unprecedented rate of $1.5-2.0 \%$ per year (Dias, 2011).

Starting from the beginning of 1990s, a number of scientific reports have highlighted the risk and/or the actual evidence of genetic erosion of the plant resources of agricultural interest in Italy (Castioni et al., 1991). These reports also attribute erosion in the Italian agricultural context to socio-economic reasons (abandonment of rural areas, aging of the growers population, availability of young people to store seeds on-farm, little passage of information from one generation to the next and, therefore, loss of knowledge and historical memory), which can vary in relation to the type of genetic resource and location (Hammer and Laghetti, 2005; Laghetti et al., 2009).

For example, Hammer and Laghetti (2005), by comparing the results 
of two successive campaigns of germplasm collection in Southern Italy (in 1950 and 1983/86), found that of the 103 local varieties mapped during the initial survey in 1950, only 28 were still grown after little more than thirty years (Table 5). Among the examined crops, vegetables showed the greatest genetic erosion per year (Table 5).

It must be underlined that in vegetable crops the risk of genetic erosion is higher because: i) the species are manly reproduced from seed, ii) monocultural systems are becoming more and more popular, iii) the market requests uniform products, iv) increasing success of new types of product (e.g. fresh-cut), v) nursery sector needs standardized cultivars (organizational reasons), vi) less and less time is dedicated to food preparation (vegetables with low difficulty in preparation), vii) more productive varieties, standardized, and homogeneous (but with a narrower genetic base) are continuously being produced by the seed companies.

In addition, in Italy as well as in other European Countries, vegetables have also been cultivated in many different family gardens surrounding urban areas. Very often, however, these areas have been affected by intense building activity that has irreversibly subtracted from agriculture, areas traditionally used for horticulture with considerable loss of agro-biodiversity and especially that based on the old varieties grown for family consumption.

In the last fifty years the industrialization of agriculture has drastically changed the landscape of rural areas throughout Europe. Crop uniformity has taken place of crop diversification, favoured by factors such as production efficiency, cost-effectiveness analysis and standardization of production inputs.

Public policies (including the CAP), market dynamics and the needs of the processing industry and the modern distribution chain have pushed agricultural systems toward greater specialization, with the intensification of monoculture. The development of industrial agriculture has produced a sharp increase in the yield per hectare, but, on the other hand, it has condemned to abandonment and subsequent extinction many previously grown species/varieties which are less quantitatively competitive.

Globalization has also stimulated the consolidation of vegetable seed companies into huge corporations and the decline of small seed companies that served local and regional markets. Some landraces and old open-pollinated varieties of vegetables have existed for long periods outside commercial and professional plant breeding circles because they have been kept alive within communities by succeeding generations of seed savers.

Unfortunately, there are fewer and fewer active seed savers among the millions of vegetable growers, due to the demand of commercial markets and the professionalization of the sector. This is an additional threat to genetic biodiversity. Thus the continued survival of landraces and open-pollinated varieties of vegetables depends largely on popular interest and initiatives as well as preservation in gene banks (Dias, 2011), as also suggested in the $2^{\text {nd }}$ report on the State of the World's Plant Genetic Resources for Food and Agriculture of FA0, which concluded that special efforts are needed to conserve biodiversity both in situ and ex situ, as well as to develop a strong capacity to use it, especially in the developing world (FA0, 2010).

\section{The vegetable biodiversity in Puglia region}

Puglia region, the most eastern region of Italy, is relatively long (350 $\mathrm{km})$ and narrow $(60 \mathrm{~km})$, extends from NW to SE and is largely open to the Adriatic and Ionian seas with a coastal zone of nearly $800 \mathrm{~km}$. Its area is $19,358 \mathrm{~km}^{2}$ with $4,090,402$ inhabitants.

The climate is mainly of Mediterranean semi-arid type, character- ized by hot dry summer and a moderately cold rainy winter season.

The region is prevalently level to slightly sloping, with more than $60 \%$ of territory below $200 \mathrm{~m}$ asl. The high steep land zones are only located in the NE (Gargano) and NW (Sub-Apennine Dauno) with several peaks of more than $1000 \mathrm{~m}$ above sea level. Its geographical length (territories are divided from each other by different traditions in vegetable cultivation) and its variety of orographic and pedoclimatic conditions gives rise to the numerical and quantitative richness of vegetables grown in the region.

Puglia, which contributes with about $22 \%$ to the Italian vegetable growing area, is among the leading regions for the productions of broccoli raab (50.4\% of national production), celery (47.7\%), parsley (42.2\%), processing tomato (35.3\%), artichoke (31.7\%), endive and escarole (25.3\%), cabbage (23.1\%), fennel (22.4\%), lettuce (22.4\%), cucumber $(22.3 \%)$, cauliflower and broccoli $(21.5 \%)$, early potato (21.3\%), asparagus (20.6\%) (ISTAT, 2012).

According to the most recent statistical data (Figure 4), Puglia produces 2.4 million tons of vegetables. In the list of Italian regions, Puglia is followed by Emilia-Romagna, Sicily and Campania. In contrast, in the ranking of regions in terms of number of vegetable varieties registered in the national catalogue, Puglia is in eighth place with just 24 registered varieties (Figure 4).

The region, which has a long tradition in vegetable growing, is particularly rich in local vegetable varieties, obtained by farmers themselves after repeated simple selection procedures generation after generation. Nowadays this richness could meet the needs of specific or niche markets, such as those characterized by the demand for local products, obtained with environmentally friendly farming techniques. The local varieties for which there is a strong link with the Puglia traditions are: carota di Polignano (Polignano carrot) and carota di sant'Ippazio (Saint Ippazio carrot) (Apiacee), asparagus, cipolla di Acquaviva delle Fonti (Acquaviva delle Fonti onion), cipolla bianca di Margherita (Margherita white onion), cipollotti (scallions) and lampascione (Leopoldia comosa (L.) Parl.) (Liliaceae), cavolfiore (cauliflower), cavolo broccolo (broccoli) - cima nera (black head), cavolo riccio (curly kale), mugnoli - and cima di rapa (broccoli raab) (Brassicaceae), squash, unripe melon - carosello, barattiere, meloncella, etc., as well as meloni d'inverno (winter melon) (Cucurbitaceae), fagiolino dall'occhio (black eyed bean) (Leguminosae), artichoke,

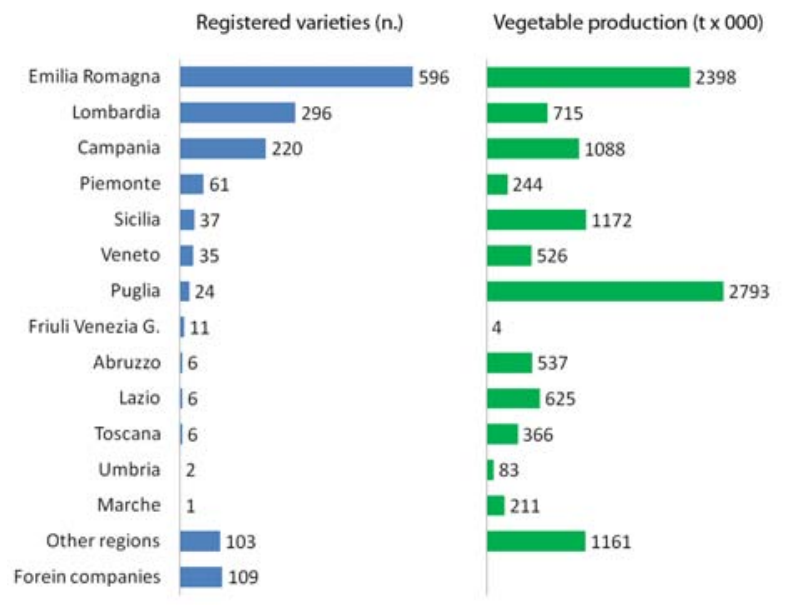

Figure 4. Comparison between the number of vegetable varieties registered by seed companies located in the different Italian regions and the vegetable production obtained in the same regions [our elaboration of data from SIAN (2012) and ISTAT (2012), both databases refer to 2011]. 
Roman lettuce and Catalogna chicory - Molfetta's chicory and Galatina's chicory (Asteraceae), pomodoro da serbo (a typical southern Italy tomato landrace characterized by a long shelf-life, which is stored fresh in typical hanged crowns for more than six months) (Solanaceae).

Examples of the wide availability of genetic resources for the typical Puglia vegetables are reported in the literature: 106 local varieties of broccoli raab (Fanizza et al., 1992; Calabrese et al., 2003), 100 of winter melon (La Malfa and Bianco, 2006), 37 of carosello and barattiere (Conversa et al., 2005). Table 5 contains the Puglia vegetable landraces at risk of erosion.

\section{Broccoli raab (Cima di rapa)}

Broccoli raab (Brassica rapa L. subsp. rapa sylvestris var. esculenta) (Figure 5) is an ancient species of Mediterranean origin. Linked to the food traditions of a large part of Central-Southern Italy, this species is mainly cultivated in Puglia, where, since July 2006, it has been included in the list of regional traditional products [Agri-food Traditional Products (ATP), see below]. In Italy 9479 ha are cultivated with broccoli raab, $92 \%$ in Southern regions, among which 4200 ha in Puglia (ISTAT, 2012).

In the last decades however this vegetable has attracted the attention of an increasing number of consumers in Northern Italy, and, following the footsteps of the Italian emigrants, it has reached other countries in Europe, the United States, Canada, Argentina and Australia. In North America it is also known by the names of broccoli rabe, broccoli de rabe, raab, rapa, rappini, rapini, spring broccoli, italian turnip and taitcat (Di Gioia and Santamaria, 2009).

As a consequence of its popularity in Puglia and thanks to the long work of selection carried out by farmers, a consistent number of cima di rapa local varieties are disseminated throughout the region. These are characterized by large variability, especially in relation to the cycle length (mostly intended as the time period between planting and the appearance of the main inflorescence).

Populations can be divided into early, mid and late varieties. They take their name from the area of cultivation or by the length of the crop cycle, from the most likely time of harvest, from the size of the inflorescence or from two or more of the above features.

The early populations, such as Quarantina (Forty-days), have very short cycle, which can be completed in about 45 days. They do not produce large inflorescences with flower buds that tend to bloom very early. In term of cycle length, Quarantina landrace is followed by Cinquantina (Fifty-days), Sessantina (Sixty-days), Novantina (Ninetydays), Centoventina (Hundred-and-twenty-days), Natalina (Christmastype), di Gennaio (from January), di Febbraio-Marzo (from FebruaryMarch), di Marzo-Aprile (from-March-April), etc. (Fanizza et al., 1992; Calabrese et al., 2003; Di Gioia and Santamaria, 2009).

The medium cycle populations, i.e. those harvested in winter from December (Natalina) until February, produce a greater number of leaves (which also have a higher biomass) and larger inflorescences, from which the name cima grande (big head) attributed to some of these populations. In these cases, the main stem appears 40-50 days after sowing.

The late or spring populations are harvested from March until AprilMay. In these local varieties the main inflorescence has improved qualitative characteristics: it emerges from the center of the plant leaf rosette 4-5 months after seed germination and can reach $15 \mathrm{~cm}$ in diameter, so much that it can be confused with a broccoli head.

Despite the crop being widespread, little genetic work has been carried out on this species and no single variety is recorded in the Italian or European register of vegetable varieties. The existing variability, expressed through the large articulation of local varieties, is essentially retained and maintained by local farmers and by some seed companies on a regional (De Corato, Fuscello, Larosa, Zagaria) and national scale (Arcoiris, Blumen, F.lli Ingegnoli, Four, Hortus, Italsementi, L'Ortolano, Royal Sluis).

\section{Catalogna chicory (Cicoria catalogna)}

The term chicory (Cichorium intybus L.) (Figure 6) is used for several different cultivated vegetables, or wild plants, used raw for the preparation of salads, or cooked for the realization of appetizers, first courses and side dishes.

The different types seem to have originated from $C$. intybus var. silvestre Bischoff, a spontaneous chicory with a thin root, to which are attributed the current varieties grown for their roots $(C$. intybus var. sativus) or leaves (C. intybus var. foliosum).

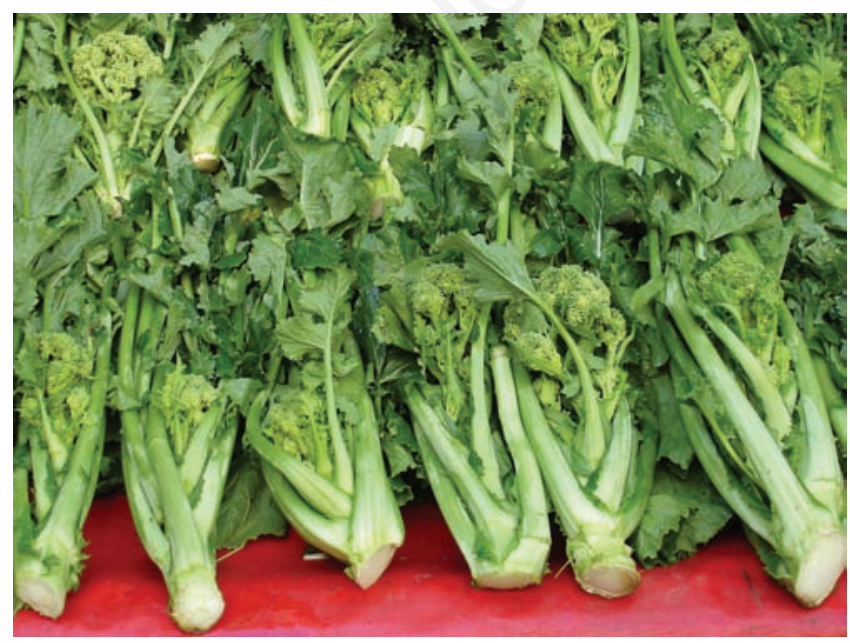

Figure 5. Broccoli raab (Cima di rapa) (Brassica rapa subsp. sylvestris var. esculenta).

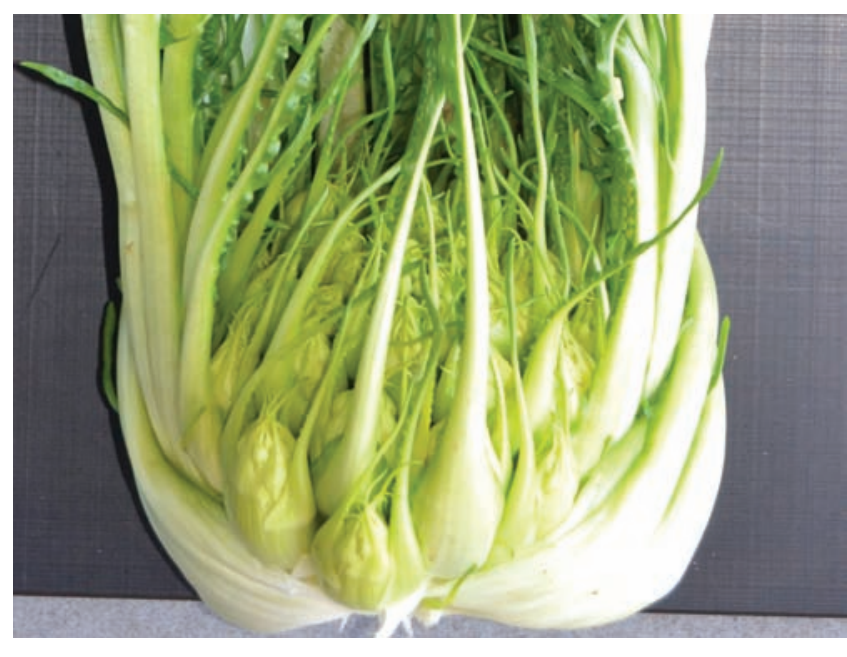

Figure 6. Catalogna chicory (Cicoria catalogna) (Cichorium intybus L.) (courtesy of Maria Gonnella). 
Among the various types, each with different biological and morphological characteristics, the Catalogna group includes various local varieties that have a head consisting of numerous shoots, similar in appearance to asparagus spears, hence also the name of asparagus chicory (Lucchin et al., 2008; Calabrese et al., 2009). The plants of the Catalogna group, as for the other types of $C$. intybus, seem to come from western Asia (Lucchin et al., 2008; Bianco and Calabrese, 2011); one of the areas of domestication seems to be Puglia, with particular reference to the Salento area (Lecce and Brindisi provinces).

In various places of Puglia these chicory are indicated with different names, including Catalogna puntarelle, Brindisina, di Galatina, Pugliese, and Molfettese; a typical population, mainly cultivated in summer, the so-called cicoria all'acqua (water chicory) or Otrantina, continuously produces elongated shoots after being subjected to repeated cuts (Bianco and Calabrese, 2011). Very often the seed is produced by farmers, through the selection of the best morphological and physiological traits. The diffusion and consumption of puntarelle chicory mainly concerns regional areas, and it is mostly used as a raw vegetable, even seasoned as salad with olive oil, with garlic and anchovies (in the most famous version in Lazio region) or cooked (in Puglia). Typically the crop has a winter-spring growing period. From the first sowings (or transplanting) to the last harvest the growing period covers up to nine months, with harvesting that starts in November and stops at the end of April. The long period of cultivation is ensured by scalar transplants, scalar maturation (within the same plot) and the use in succession of the Molfettese population (more cold resistant) followed by Galatina (more sensitive to cold, due to the more crunchy and tender texture of its shoots). Also in this case, the genetic improvement in this type of chicory is poor, essentially based on selection work carried out by farmers and some seed companies. Four varieties are registered on the national register (from the Larosa, De Corato, SAIS and Blumen seed companies). The Catalogna type also includes some local varieties of chicory mainly grown in the Veneto region that do not form a head (Catalogna di Chioggia, Catalogna del Veneto, Catalogna a foglie frastagliate).

\section{Carosello and barattiere}

Carosello and barattiere (Figure 7) are herbaceous plants belonging to Cucumis melo L. species. Numerous local varieties are grown in Puglia (Conversa et al., 2005) which differ in the shape, colour and size of the fruit. The fruits are consumed at the immature stage, fresh and raw, instead of cucumbers, due to their better quality profile. They are characterized by being refreshing and digestible as well as having high potassium and low reducing sugar and sodium contents (Serio et al., 2005). The harvest is typically carried out when the fruits have a crunchy and a consistent flesh texture, the seeds are still barely visible and the placenta cavity is absent. The carosello fruits can have different forms (from cylindrical to spherical), variable weight (from about 50 to over $300 \mathrm{~g}$ ), rind colour from light green to very dark green, uniform or mottled, and can present more or less dense pubescence (Bianco et al., 2003).

Barattiere differs from carosello essentially in the form of fruits, which are more spherical, slightly tapered in the peduncle zone. The surface is glabrous, of various hues of colour from grey to green.

The flesh is light green tending to pink in most mature fruits, crunchy first, then more and more soft and tasty. At physiological ripening the epicarp turns yellow and the flesh becomes sweet with melon flavour and aroma. The fruit reaches a weight of from $200 \mathrm{~g}$ to more than $1 \mathrm{~kg}$ and are produced in a number of 2-10 per plant (Bianco, 1990a). The local varieties take their name from the areas of cultivation, from the colour and the shape of the fruits: Carosello barese, Mezzo lungo barese, Carosello di Polignano, Mezzo lungo di Polignano, Tondo liscio di Manduria, Locale di Brindisi, Verde chiaro di Casamassima, Mezzo lungo scopatizzo, Verde scuro, Spuredda bianca leccese, Spuredda nera, Carosello di Fasano cianciuffo, Barattiere di Fasano, Meloncella, etc. For these local varieties there are serious difficulties in the use of chemical control methods due to the frequent and long period of harvest. Carosello showed a higher sensitivity to powdery mildew than barattiere (Buttaro et al., 2009).

The seeds for propagation are typically produced on-farm by the

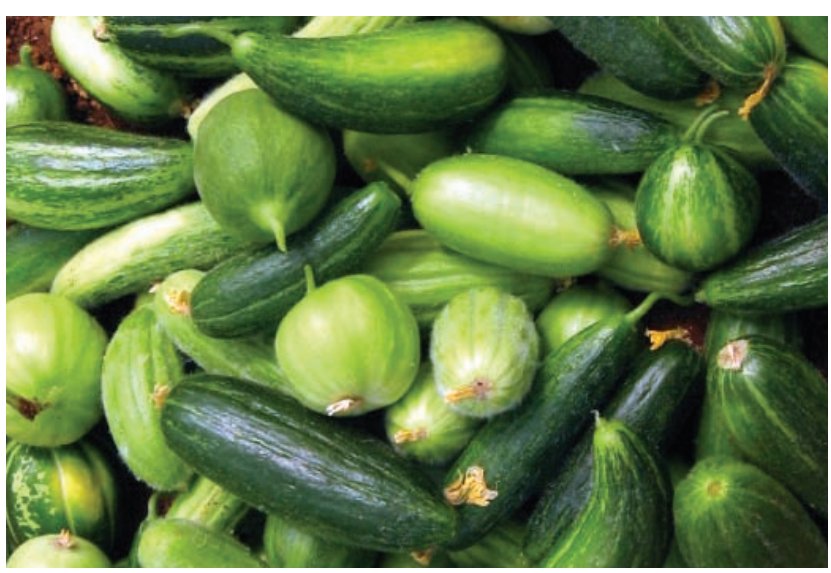

Figure 7. Carosello and barattiere fruits (Cucumis melo L.).

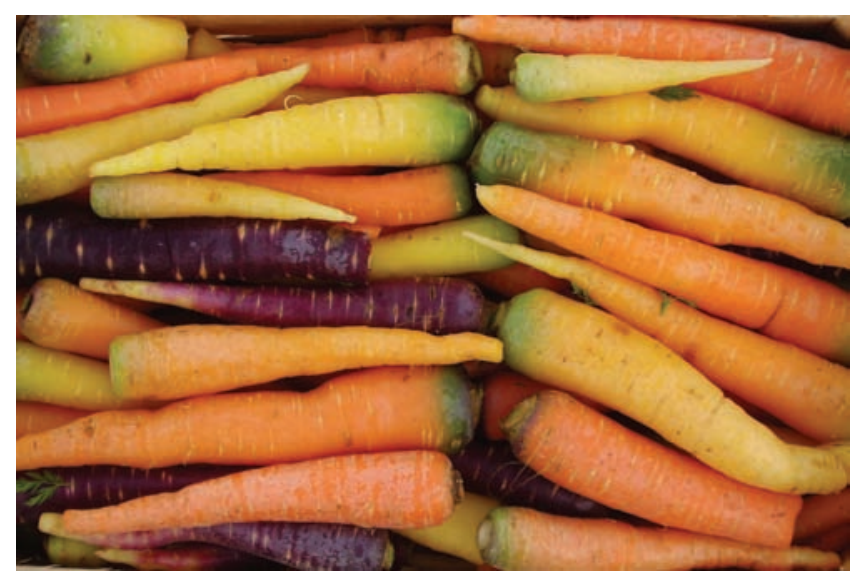

Figure 8. Polignano carrot (Carota di Polignano) (Daucus carota L.). 
growers. There are some seed companies which distribute the more interesting local varieties. It must be mentioned that frequently they cause cases of synonymy and confusion between and within the two main groups. On the national register there are no registered varieties of carosello or barattiere. None of local varieties have been subject to an organic work of genetic improvement.

There are no available statistical official data on the cultivation of these vegetables. A cultivated area of about 100 ha is estimated in Puglia, mainly in the open field but also in greenhouse and small tunnel conditions. The diffusion and the consumption of carosello and barattiere, initially limited to some areas of Puglia, is extending beyond regional borders, also involving organized distribution.

\section{Carota di Polignano and carota di sant'Ippazio}

In the Puglia region, a multicoloured local variety called the yellowpurple Polignano carrot (Figure 8) has been grown since 1940 by local smallholder farmers (Cefola et al., 2012). The length of these carrots ranges from 15 to $25 \mathrm{~cm}$, while the diameter can reach $5 \mathrm{~cm}$. They are characterized by a special sweetness, crispiness and fragrance and by a great variety of colours in the external (outer core or cortex) and internal (inner core) root tissues. The cortex pigmentation or colour ranges from yellow or deep orange to dark purple, while the inner core colour ranges from pale yellow to light green. This local variety has been added to the Slow Food list of traditional products by the Slow Food Association (Slow Food, 2012a). In addition, it is included on the list of vegetables at risk of genetic erosion in the Rural Development Program of the Puglia region 2007-2013 (Table 6).

In a recent paper, Cefola et al. (2012) show that total glucose, fructose, and saccharose content is $22 \%$ lower in the yellow-purple Polignano carrot than in the commercial one. In addition, the highest contributor to the relative sweetness in the yellow-purple Polignano carrot is fructose (43.5\%), which affects its well-known taste, as well as its glycemic index. As for the nutritional parameters, purple carrots showed the highest content in antioxidant activity, total phenols, carotenoids and $\beta$-carotene, mainly detected in the cortex.

The interesting aspect of this landrace is that the product can achieve excellent prices, generally twice or three times more than the

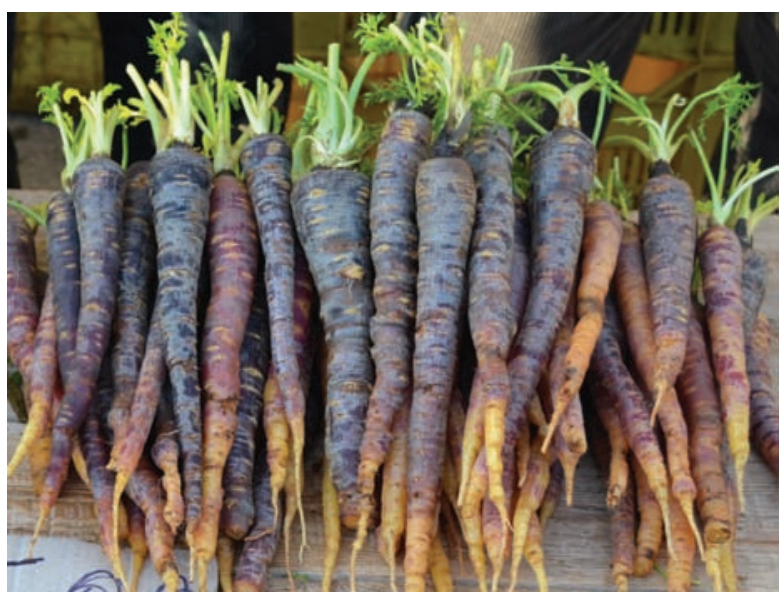

Figure 9. Saint Ippazio carrot (Carota di sant'Ippazio) (Daucus carota $\mathrm{L}$.).

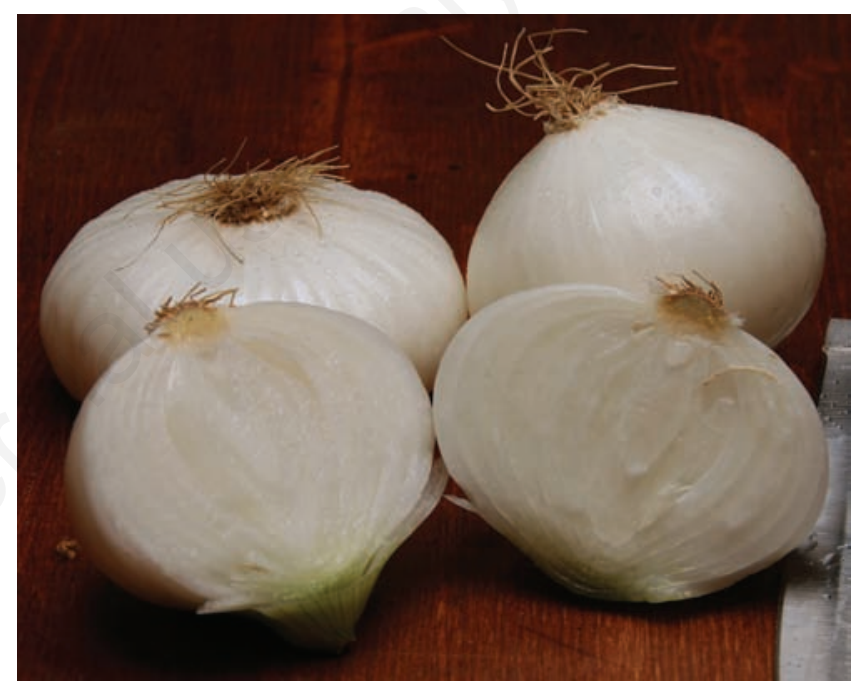

Figure 10. Margherita white onion (Cipolla bianca di Margherita) (Allium cepa L.) (courtesy of Giuseppe Castiglione).

Table 6. Puglia vegetable local varieties at risk of erosion (included in annex 8 of the Rural Development Program 2007-13 (RDP Puglia).

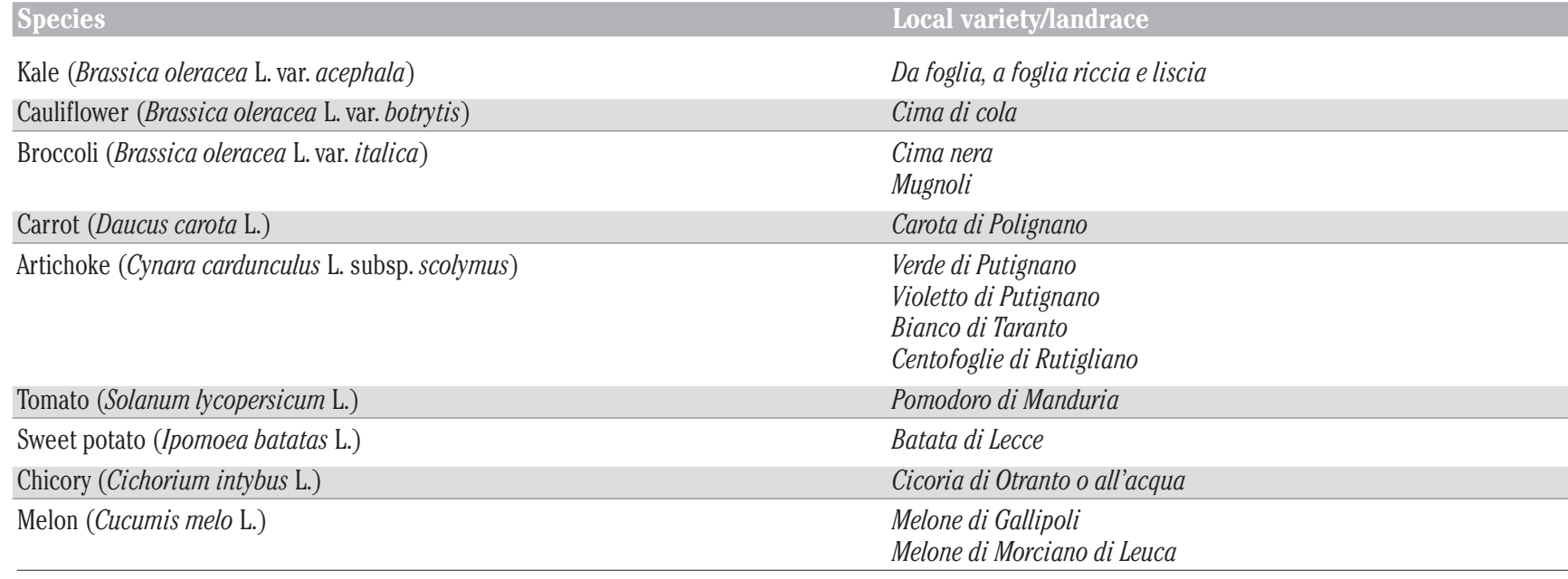




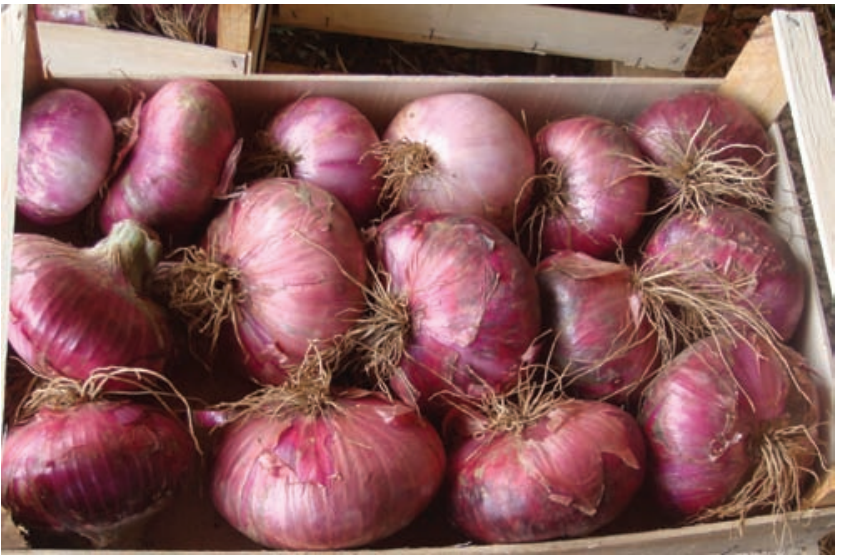

Figure 11. Acquaviva delle Fonti onion (Cipolla di Acquaviva delle Fonti) (Allium cepa L.) (courtesy of Luigi Ricciardi).

orange commercial carrots. The carrot of sant'Ippazio or di Tiggiano (Figure 9) is a local variety of purple and yellow colour, cultivated almost exclusively in the province of Lecce, in the territory of Tiggiano, Tricase and Specchia villages. Its survival is due to the popular devotion toward saint Ippazio, protector of virility and groin hernia as he was suffering from these problems following a kick received from an Arian heretic. By tradition during the feast in honour of Saint Ippazio (19 January) the people of Tiggiano sell these carrots. Until not long ago, women brought the underpants of their husbands as a votive offering to the Saint to preserve them from woes and hernias, as well as protecting their manhood.

\section{Cipolla di Margherita and cipolla di Acquaviva delle Fonti}

The cipolla bianca di Margherita (or cipolla di Margherita, cipolla di Zapponeta, cipolla delle saline) (Figure 10) is an ATP (see below). This onion is cultivated along the Adriatic sea coast on the sandy soils close to the beaches from the Candelaro river, north of the village of Zapponeta, to the Ofanto river in the territory of Margherita di Savoia. Traces of its cultivation in the area date back to the early 1700 s.

Thanks to the genetic characteristics of the local varieties of Margherita onion, selected over centuries by farmers, and to the particular pedo-climatic environment, this onion is characterized by early production, tender and crunchy bulbs with a high degree of sweetness.

Farmers use different local varieties selected over centuries for: i) their ability to adapt to the particular soil and climatic conditions of the territory; ii) different degree of earliness (Marzaiola, Aprilatica, Maggiaiola, Giugnese and Lugliatica); iii) and the size and shape of bulbs.

The late ecotype of this onion (Agostana) was abandoned due to the strong competition of the product coming from hybrid varieties.

The Cipolla di Acquaviva delle Fonti (Figure 11) is renowned for its sweetness and is recognized by its colour (between carmine red and purple, that becomes lighter toward the inside, until it becomes completely white) the typical flattened form (2-3 cm longitudinal axis/10-12 $\mathrm{cm}$ horizontal axis) and the weight that can reach $500 \mathrm{~g}$.

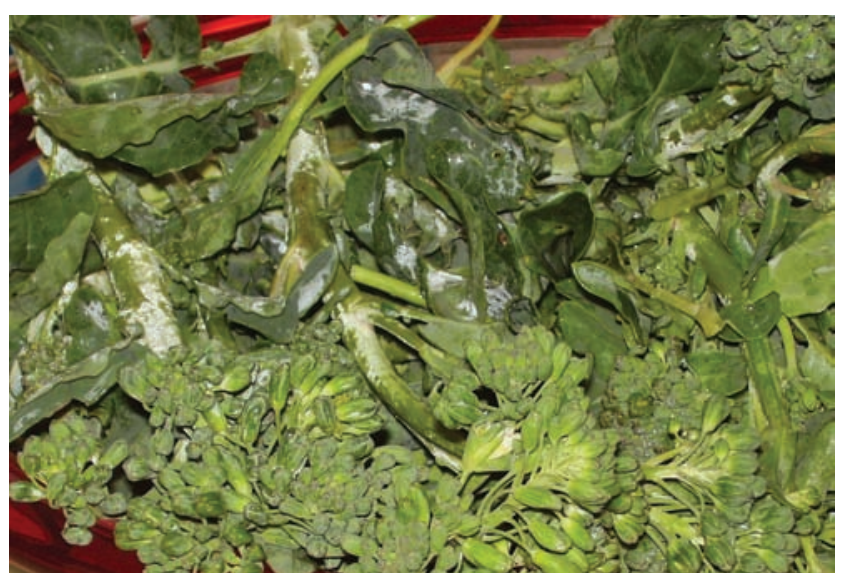

Figure 12. Mugnoli broccoli (Mugnoli) (Brassica oleracea L. var. italica).

The name of the onion comes from the village Acquaviva delle Fonti where is mainly cultivated, whose name is linked to the large availability of underground fresh water. The bulbs grown in this territory, since the 1800 s, are appreciated for their quality and even sold on markets beyond the local region.

The cultivation of these local varieties of onion remains largely based on manual labour. There are no registered varieties of either of these onions and their seeds are only stored by farmers who have handed down the seeds from one generation to another.

This local variety has been added to the Slow Food list of traditional products by the Slow Food Association (Slow Food, 2012b).

\section{Use of edible spontaneous plants as vegetables}

A particular segment of the biodiversity in Puglia is represented by the food use of spontaneous edible plants, which includes some progenitors of cultivated vegetables with which there is a continuum in the genetic profile.

The food use of wild herbs is deeply rooted in the tradition of the region and they are part of many regional recipes. For example in the Foggia cuisine, wild vegetables alone or in combination with pasta, bread (pancotto) or pulses, are always present on local tables.

The historical figure of terrazzani, who are collectors and sellers of wild herbs, mushrooms, frogs, snails and lampascioni, is typical in Capitanata (Foggia province). Still today examples of this singular figure of ante litteram ecologist can be found at the local markets in Foggia and its province with their rich load of spontaneous biodiversity collected in the woods and the neighbouring rural areas.

The following are significant examples for Puglia: wild cardoon, wild asparagus, rocket, wild chicory, purslane, some leaf beets and many other species (Bianco et al., 2009; Gonnella et al., 2010). Of course these species have an interest not only as a source of food, but also as a reserve of genetic resources from which to draw on for the purposes of genetic improvement and to give rise, through domestication, to new crops (Bianco et al., 1998).

Bianco et al. (2009) reports a list of 532 spontaneous species present in the Puglia region (out of a total of 2500 that compose the Puglia flora) which have been used in the past and until recently as food, indi- 
cating the botanical family and name, common name, frequency in the territory, the edible part and how it is prepared.

Investigations and research has been carried out in the past three decades both at the University of Bari and at the ISPA-CNR Institute (former ISOI-CNR) on these herbaceous and spontaneous edible plant species, all aimed at identifying the existing species on the Italian and Puglia territory as well as their morphological, biological and qualitative characterization.

Some of these species have been subjected to more or less successful attempts of cultivation. Cultivation attempts have been recorded in 122 of the 532 spontaneous edible species, both in the open-air and in protected environments and even with soilless systems (Bianco et al., 2009).

The cultivation may also serve to preserve the spontaneous flora biodiversity that, following the increased decrease in rural land by intense urbanization, and uncontrolled collection, are likely to lead to the impoverishment and subsequent disappearance of these species.

The cases of lampascione, wild asparagus, wild cardoon, borage, wild fennel, silene, sage and rosemary are indicative in this respect. Among these examples of domestication, one of the most successful is that of wild rocket (Diplotaxis tenuifolia (L.) DC.), which since the first attempts in Italy in early 1990s, is currently grown over an area 1,000 ha, mainly in greenhouses. $D$. tenuifolia was first described in Italy by Petrollini and Cibo in 1550 (Bianco et al., 2009). Since 1990 there has been an increase in its consumption also due to the initiatives of some great chefs who proposed rocket in various recipes. Thus, for example, rocket is used as an ingredient in risotto, gnocchi, tortellini, different types of pasta, pizzas, piadine, with canapés and bruschetta and to prepare carpaccio. In addition, it is used by small scale artisan processors to prepare creams, sauces and pesto. The most important boost, however, came from the massive demand from the fresh-cut industry.

The multidisciplinary research carried out by various Italian research institutions, in particular those in Bari, has greatly contributed to this success by conducting research that has focused on the physiological, agronomical and qualitative aspects of this species and also by offering useful practical suggestions for its exploitation to all operators in the sector.

\section{Tools for the conservation of vegetables biodiversity in Puglia region}

Puglia region has inserted specific actions within Axis 2 Improvement of the environment and of the rural areas and of measure 214 Agro-enviromental payments in the Rural Development Program 2007-13 (RDP Puglia) for the preservation and promotion of biodiversity. More specifically, action 214/3 Protection of biodiversity provides for financial support for a five-year period for guardians farmers committed to preserving in situ the plant genetic resources listed in the annex to the RDP (14 local varieties of vegetables; Table 6). In action 214/4 there are Integrated projects and regional biodiversity system. These projects are intended to create a network on biodiversity to promote the exchange of information between stakeholders in the diffusion and protection of genetic resources in agriculture. They also use specific and integrated research projects funded to develop the collection of knowledge, based on experimental evidence and the collection of plant material at risk of extinction, its retrieval and identification in the territory, its characterization, its maintaining through seed multiplication under sanitary controlled conditions, cataloguing and conservation.

\section{Biodiversity and traditional products}

Biodiversity is also tradition and gastronomy. In Puglia, vegetable species biodiversity also means types of vegetables unknown elsewhere: succiamele delle fave (Orobanche crenata Forssk.) (Bianco et al., 2009), cardoncello (Scolymus maculatus L. - Spotted golden thistle) (Bianco et al., 2009), mugnoli (Figure 12) (Argentieri et al., 2011) and cima nera (Table 6), to name just a few. According to the definition of biodiversity proposed by the FAO, traditional knowledge may be regarded as an integral part of agro-biodiversity, because it is the human activity that forms and saves this biodiversity (FA0, 2009).

For this reason we must also take into account ATP that represent a visiting card for the quality of Italian agriculture. The ATPs refer to agri-food products whose methods of processing, conservation, and maturation are maintained over time, are consistent throughout the interested territory, according to traditional rules, for a period of not less than 25 years.

Often ATPs have limited production in terms of quantity and interest very restricted territorial areas, but can have a significant effect on those plants at risk of erosion.

The exploitation of these productions must be integrated into the potentiality of the territory and the exploitation of the multi-functionality of farms, through initiatives also including farm visits and the development of commercial proposals with other complementary products.

Despite the large number of typical vegetables grown in Puglia, only Carciofo brindisino has obtained the European label of protected geographical indication (PGI), notwithstanding the popularity of the festivals (over 30 per year) celebrating typical local vegetables.

\section{Conclusions}

In Europe the highest activity of the seed industry in terms of varieties produced does not overlap with the areas of the highest production of vegetables. Among the $27 \mathrm{EU}$ countries, The Netherlands has a dominant position in terms of number of varieties and hybrids registered and in the size of its seed companies. In the rest of Europe, only France, Spain and Italy have a moderately developed seed industry. The number of varieties and hybrids registered are fewer and the seed companies are much smaller in the other countries. The contrast also appears between the different areas of vegetable production in Italy, where Puglia, which is the Italian region with the largest growing area and production of vegetables, has only 24 vegetable varieties registered in the national catalogue.

This indicates the existing divide in the vegetable crops sector between the high technological and intensive growing systems, which are supported by a continuous flow of new hybrids from a high tech seed industry more and more focused on responding to the demand of commercial markets and to the professionalisation of the sector, and the traditional growing systems based on landraces and old open-pollinated varieties, which have been kept alive within communities by generations of growers and which sometimes interest marginal environments.

The case of Puglia is emblematic: the huge richness in vegetable biodiversity which is largely used and which represents the most typical and traditional vegetable products of the region, such as, broccoli raab, Catalogna chicory, carosello and barattiere. This demonstrates the extensive use of local varieties that have existed for long periods outside commercial and professional plant breeding circles and have not been subjected to organized programs of genetic improvement. These 
local varieties are characterized by a specific adaptation to environmental conditions and cultivation, which are closely associated to the specific farming conditions, the uses, the knowledge, the habits, the dialects and the recurrences of the region. The role of vegetable growers in conserving and using this vegetable biodiversity is still fundamental.

In facing the challenges of the modern vegetable growing sector, the many expressions of vegetable biodiversity are a key source for genetic improvement programs, to produce innovative vegetables with improved qualitative characteristics (crop diversification and new crops), to realize more environmentally sustainable agro-systems, to cope with issues of climate change, to find better adaptation to marginal soil conditions (salinity, atmospheric pollutants, etc.), not forgetting the need to recover and maintain links with history and folk traditions. In this view it must be underlined that the conservation of genetic biodiversity must be based not only on institutional and private plant breeders and seed banks, but mainly on the vast number of growers who continuously select, improve, and use vegetable biodiversity at the local scale.

\section{References}

Argentieri MP, Accogli R, Fanizzi FP, Avato P, 2011. Glucosinolates profile of "Mugnolo", a variety of Brassica oleracea L. native to Southern Italy (Salento). Planta Med. 77:287-92.

Benedetti E, 1973. Produzione e commercio delle sementi. La nuova legislazione. 1st edition, Reda, Roma, Italy.

Bianchi PG, Bocci R, Bravi R, Dalla Ragione I, Di Matteo A, Fideghelli C, Fontana M, Macchia M, Maggioni L, Negri V, Pignone D, Porfiri 0, Schneider A, Sottile F, Vazzana C, 2012. Biodiversità e risorse genetiche vegetali. In: Marino M., Trisorio A. (eds) Linee guida per la conservazione e caratterizzazione della biodiversità vegetale di interesse agricolo. Piano nazionale sulla biodiversità di interesse agrario, 9-55. Mipaf, Roma, Italy.

Bianco VV, 1990a. Carosello (Cucumis melo L.). In: V.V. Bianco and F. Pimpini (eds.) Orticoltura. Patron Ed., Bologna, Italy, pp 517-521.

Bianco VV, 1990b. Classificazione delle specie orticole. In: V.V. Bianco and F. Pimpini (eds.) Orticoltura. Patron Ed., Bologna, Italy, pp 969983.

Bianco VV, 1992. Usual and speciality vegetables crops in Mediterranean countries. Acta Hortic. 318:65-6.

Bianco VV, Calabrese N, 2011. Origine ed evoluzione, morfologia e fisiologia. In: M.L. Gullino and R. Angelini (eds.) Le insalate, Bayer CropScience, Ed. Script, Bologna, Italy, pp 2-23.

Bianco VV, Damo R, Roshanji N, Mero G, 2001. Piante spontanee eduli della flora albanese. Interreg II. Italia-Albania. Asse 6. Misura 6.2., 4. Dip. Sci. Prod. Veg. Univ. Bari, Italy.

Bianco V, Machackova M, 2002. Specie spontanee della flora italiana utilizzabili come ortaggi e piante da condimento. Proc. VI Giornate Scientifiche SOI, Spoleto (PG), Italy, 2:435-6.

Bianco VV, Mariani R, Santamaria P, 2009. Piante spontanee nella cucina tradizionale molese. Levante Ed., Bari, Italy.

Bianco VV, Parente A, Conversa G, 2003. Caratterizzazione di popolazioni di melone da consumo 'verde'. Inf. Agrario 59:4-5.

Bianco VV, Santamaria P, Elia A, 1998. Nutritional value and nitrate content in edible wild species used in southern Italy. Acta Hortic. 467:71-87.

Branca F, 1991. Studi su specie della flora spontanea di interesse alimentare. Degree Diss., University of Catania, Italy.

Buttaro D, Bonasia A, Minuto A, Serio F, Santamaria P, 2009. Effect of silicon in the nutrient solution on the incidence of powdery mildew and quality traits in carosello and barattiere (Cucumis melo L.) grown in a soilless system. J. Hortic. Sci. Biotech. 84:300-4.

Calabrese N, Pace B, Cantore V, Carito A, Damato G, 2009. Epoche di raccolta, produzione e qualità di cicoria catalogna per la surgelazione e la IV gamma. Riv. Agron. 4:559-64.

Calabrese N, Signorella G, Bianco VV, 2003. La cicoria catalogna e la cima di rapa: due ortaggi tipici della Puglia. Italus Hortus 10:21822.

Castioni F, Cerretelli G., De Meo A, Nota D, Paderi S, Righini M, Tartoni G, Vazzana C, 1991. Un seme, un ambiente. Ricerca di germoplasma di specie erbacee di interesse agricolo in Toscana. Regione Toscana, Giunta Regionale, Firenze, Italy.

Cefola M, Pace B, Renna M, Santamaria P, Signore A, Serio F, 2012. Compositional analysis and antioxidant profile of yellow, orange and purple Polignano carrots. Ital. J. Food Sci. 24:284-91.

Conversa G, Gonnella M, Santamaria P, Bianco VV, 2005. Caratterizzazione e valorizzazione di due tipici ortaggi pugliesi: carosello e barattiere. Colt. Prot. 34:4-13.

Di Gioia F, Santamaria P, 2009. Ai mercati piace la cima di rapa pugliese, ortaggio "antico". Ortofrutta Italiana 6:100, 102-104, 106-107.

Dias JCS, 2011. Biodiversity and vegetable breeding in the light of developments in intellectual property rights. In: 0 . Grillo and G. Venora (eds.) Ecosystems biodiversity. Intech, Rijeka, Croatia, pp $389-428$.

Eurobarometer, 2010. Attitudes of Europeans towards the issue of biodiversity. Flash Eurobarometer n. 290. Draft analytical report, Wave 2. Available from: http://ec.europa.eu/public_opinion/flash/fl_ 290_en.pdf Accessed: 24 October 2012.

European Commission, 2011. Common catalogue of varieties of vegetable species. Fifth supplement to the 29th complete edition. In: Official Journal, C 244 A/01, 23/8/2011, pp 23.

Fanizza G, Damato G, Bianco VV, 1992. A multivariate morphometric study on landrace differentiation in broccoli raab (Brassica rapa L.). Acta Hortic. 318:195-200.

FA0, 2009. Report on the state of the World's plant genetic resources for food and agriculture. Available from: http://www.fao.org/agriculture/crops/core-themes/theme/seeds-pgr/sow/en/

FAO, 2010. The second report on the state of the World's plant genetic resources for food and agriculture. Available from: http://www. fao.org/agriculture/crops/core-themes/theme/seeds-pgr/sow/en/

FAOSTAT, 2012. Crops production statistics. Available from: http:/faostat.fao.org/default.aspx Accessed: 10 September 2012.

Frankel OH, Brown ADH, Burdon JJ, 1995. The conservation of plant biodiversity. Cambridge University Press, Cambridge, UK.

Gonnella M, Charfeddine M, Conversa G, Santamaria P, 2010. Purslane: a review of its potential for health and agricultural aspects. Eur. J. Plant Sci. Biotech. 4:131-6.

Hammer K, Laghetti G, 2005. Genetic erosion: examples from Italy. Gen. Res. Crop Evol. 52:629-34.

ISTAT, 2012. Electronic Information System on Agriculture and Livestock. Italian National statistical Institute (ISTAT), Rome. Available from: http://agri.istat.it/ Accessed: 10 September 2012.

Kays SJ, Dias JS, 1995. Common names of commercially cultivated vegetables of the world in 15 languages. Econ. Bot. 49:115-52.

Kays SJ, Dias JS, 1996. Cultivated vegetables of the world. Latin binomial, common names in 15 languages, edible part, and method of preparation. Exon Press, Athens, GA, USA.

La Malfa G, 1997. Principali profili dell'orticoltura amatoriale. pp 7-16 in Atti giornate tecniche SOI, Cesena (F0), Italy.

La Malfa G, Bianco VV, 2006. Agrobiodiversità nel settore orticolo: espressioni e nuove esigenze. Italus Hortus 13:31-44.

Laghetti G, Fiorentino G, Hammer K, Pignone D, 2009. On the trail of the last autochthonous Italian einkorn (Triticum monococcum L.) 
and emmer (Triticum dicoccon Schrank) populations: a mission impossible? Gen. Res. Crop Evol. 56:1163-70.

Lee SH, 1992. Vegetables growing in China. Sci. Hortic. 17:201-9.

Leonardi C, 1993. Studi su specie da orto ai fini della innovazione colturale. Degree Diss., University of Catania, Italy.

Lin Chao H, 1989. Diversification and marketing status of vegetable crops in Oriental tropics. Acta Hortic. 242:45-58.

Lucchin M, Varotto S, Barcaccia G, Parini P, 2008. Chicory and endive. In: J. Prohens-Tomás and F. Nuez (eds.) Vegetables I: Asteraceae, Brassicaceae, Chenopodiaceae, and Cucurbitaceae. Springer Science, New York, NY, USA, pp 3-48.

Rubatzkj VE, Yamaguchi M, 1997. World vegetable. Chapman \& Hall, New York, NY, USA.

Serio F, Florio G, Parente A, Santamaria P, 2005. Confronto tra sistem di coltivazione di carosello e barattiere in serra. II. Aspetti qualitativi. Colture Protette 34:28-35.

SIAN, 2012. Elenco delle varietà di specie ortive iscritte nel registro. Available from: http://www.sian.it/portale-sian/sottosezione.jsp? pid=10 [ select: "Stampa dei registri delle varietà vegetali/Registro Ortive.pdf Accessed: 12 September 2012.

Slow Food, 2012a. I presidi Slow Food in Italia. Carote di Polignano.
Available from: http://www.fondazioneslowfood.it/pagine/ita/presidi_italia/dettaglio_presidi.lasso?-id=3667 Accessed: 24 October 2012.

Slow Food, 2012b. I presidi Slow Food in Italia. Cipolla rossa di Acquaviva. Available from: http://www.fondazioneslowfood.it/pagine/ita/presidi_italia/dettaglio_presidi.lasso?-id=3257 Accessed: 24 October 2012.

Tanksley SD, McCouch SR, 1997. Seed banks and molecular maps: unlocking genetic potential from the wild. Science 277:1063-6.

Van de Wouw M, van Hintum T, Kik C, van Treuren R, Visser B, 2010. Genetic diversity trends in twentieth century crop cultivars: a meta analysis. Theor. Appl. Genet, 120:1241-52.

Viani P, 1929. Trattato di orticoltura. 1st edition. Battiato Ed., Catania, Italy.

Wilson E0, 1992. The diversity of life. Harvard University Press, Cambridge, MA, USA.

Zeder MA, Emschwiller E, Smith BD, Bradley DG, 2006. Documenting domestication; the intersection of genetics and archeology. Trends Genet, 22:139-55.

Zeven AC, 1998. Landraces: a review of definitions and classifications. Euphytica 104:127-39. 